\title{
Artículos
}

Encuentro №. 100, 6-37, 2014

\section{Mediated Intimacies: State Intervention and Gender Violence in Nicaragua}

\author{
Alicia Zoe Miklos*
}

Received: February 2015 / Accepted: April 2015

This article forms part of an inquiry about the reach of legislative changes initiated by Law 779 in Nicaragua, the "Integral Law against Violence towards Women", passed in February 2012. The primary texts I analyze include the legislative debates for the drafting of Law 779, the body of Law 779, the Reform to the law in October 2013, and the Regulations to Law 779, issued through a presidential proclamation in July 2014. I organize my discussion around the most controversial juridical figure in Law 779: that of mediation. Analyzing the trajectory of Law 779 within the Post-war cultural scene in Nicaragua, I conclude that the reinstatement of mediation represents a regressive reaffirmation of patriarchal authority in the guise of community empowerment. The family centered rhetoric of the Regulation to Law
Este artículo forma parte de una investigación sobre los cambios legislativos iniciados por la Ley 779 en Nicaragua, "Ley Integral contra la Violencia hacia las Mujeres", aprobada en febrero de 2012. Los textos primarios que analizo incluyen los debates parlamentarios para el anteproyecto de la Ley 779 , el cuerpo original de la Ley 779, las Reformas de octubre de 2013, y el Reglamento a la Ley 779, emitido en un decreto presidencial en julio de 2014. Organizo el análisis alrededor de la figura jurídica más polémica de la Ley 779: la mediación. Al analizar la trayectoria de la Ley 779 dentro del escenario de posguerra en Nicaragua, concluyo que el restablecimiento de la mediación representa una reafirmación regresiva de la autoridad patriarcal bajo el disfraz de empoderamiento comunitario. La retórica centrada 
779 signifies capitulation to the most conservative, religious sectors of society and a dramatic reversal of feminist gains towards recognizing women as subjects with rights. These are in fact battles over the cultural interpretation of women's place, their autonomy, and the troubled reality of the nuclear family and normative social bonds in twenty-first century Central America. They show that women's autonomy continues to be symbolically coded as dangerous, even as a threat to the collective interests of the family and the nation.

Keywords: Law 779 / Legislation on gender violence / Femicide / Mediation en la familia del Reglamento a la Ley 779 implica una capitulación a los sectores más conservadores y religiosos de la sociedad y un revés dramático de los logros feministas hacia el reconocimiento de las mujeres como sujetos de derechos. De hecho, estas son batallas sobre la interpretación cultural del lugar de la mujer, su autonomía y la realidad turbulenta de la familia nuclear y los lazos sociales normativos en la Centroamérica del siglo XXI. Muestran que la autonomía de las mujeres sigue siendo codificada simbólicamente como peligrosa, incluso como una amenaza a los intereses colectivos de la familia y la nación.

Palabras clave: Ley 779 / legislación sobre violencia de género / feminicidio / mediación

\section{Introduction}

In a compelling scene from Florence Jaugey's documentary El dia que me quieras, which follows the police agents of the Women and Children's Police Stations (Comisaría de la Mujer y la Niñez) in Managua, Nicaragua for a day, a woman gives testimony to a police agent about her husband's abusive and controlling behavior. She describes how he manipulates her psychologically by pitting the children against her. The woman police agent listens to Liseth's story and then summons in the husband. From the start, the spectator witnesses the husband talking over and demeaning his wife, his dramatic gesticulating, and his attempt to assert his authority over both women, even alleging that things would be settled differently if they were at his home. This scene exemplifies mediation as a problematic judicial practice, given the conflicted interpersonal and institutional realms of gender relations in contemporary Nicaragua. Despite legal inroads toward enacting protective and punitive measures against gender violence, conflicts persist: crises in the nuclear family as a stabilizing structure, the dilemma of violent masculinities, and the ineptness of state institutions to deal with extreme polarization in gender relations. This is a visual archive of a disturbing and puzzling reality: today, both in Nicaragua and across the globe, the intimate, as one site of gender relations, appears wrought with trauma, disintegration, and often becomes a public spectacle. 
In the Post-war context of Central America, Nicaragua boasts being one of the safest countries. The government recently released the results of a Gallup poll that names it as the safest country in Latin America (ND, 2014a). Of the Central American countries that experienced civil wars, Nicaragua has most effectively avoided the extreme social disintegration and violence of organized crime that other beleaguered countries have faced post 1990s peace accords (Martí i Puig \& Sánchez-Ancochea, 2014, p. 112). Additionally, Nicaragua has followed the regional trend towards enacting progressive national laws against gender discrimination and violence initiated by Mexico and Guatemala. But a great tension arises between the country's shining regional reputation and the disturbing, persistent appearance of murdered women and sexually abused adolescents and girls across the landscape. ${ }^{1}$ Indeed, the image of woman-as-victim saturates the representational scene, but social debates reveal the conflicted nature of making this violence visible, when it seems to run counter to the political and economic interests of the State.

This article forms part of an inquiry about the reach of legislative changes initiated by Law 779 in Nicaragua, the "Integral Law against Violence towards Women" (henceforth known as Law 779), passed in February 2012. The primary texts I analyze include the legislative debates for the drafting of Law 779, the body of Law 779, the Reform to the law in October 2013, and the Regulations to Law 779, issued through a presidential proclamation in July 2014. I organize my discussion around the most controversial juridical figure in Law 779: that of mediation. Analyzing the trajectory of Law 779 within the Post-war cultural scene in Nicaragua, I conclude that the reinstatement of mediation represents a regressive reaffirmation of patriarchal authority in the guise of community empowerment. The family centered rhetoric of the Regulation to Law 779 signifies capitulation to the most conservative, religious sectors of society and a dramatic reversal of feminist gains towards recognizing women as subjects with rights. These are in fact battles over the cultural interpretation of women's place, their autonomy, and the troubled reality of the nuclear family and normative social bonds in twenty-first century Central America. They show that women's autonomy continues to be symbolically coded as dangerous, even as a threat to the collective interests of the family and the nation.

I work from the premise of Critical Discourse theory, expressed by Van Dijk (2001), that "the link between text and society is mediated" (p. 353), analyzing social controversies and journalistic debates around the law as equally salient and influential as the text of the law itself. Following Patricia J. Williams (1991), I emphasize the 'rhetorical' nature of the law's language, maintaining a critical stance towards what she calls the legal discourse's reliance on the supposed "existence of objective 'unmediated' voices by which those transcendent, universal truths [of the law] find their expression" (p. 8). Due to my healthy dose of skepticism towards statecentered approaches to social transformation, the central question concerns how the terminology and rhetorical gestures of the law intercede in the symbolic construction of gender norms and relations. Where are the gaps between assertions, on the legal plane, of women as inviolable, autonomous subjects on the one hand, and everyday 
social practices on the other? What can we learn from the social debate over Law 779 about the deep well springs of cultural belief about masculine authority and the array of threats that now accost it? (Not only the feminist movement, but also the Gay, Lesbian, Trans, and queer rights movements). In the end, I conclude that the law is indeed permeable by other social discourses, whether they challenge or maintain existing gender hierarchies.

The social tension wrought by the introduction of feminist concepts into Nicaraguan law reveals the limited capacity of legalistic discourse and procedure to transform deep symbolic currents of masculine supremacy and authoritarian culture. The inability of the law to mitigate both the demands of feminists and those of traditional centers of familiar and institutional-i.e. patriarchal-authority crops up through hotly contested, unresolved social debates over the law's most controversial tenets. My hypothesis is that the polemical fragments of the legislation unveil the most embattled institutional and ideological bastions of masculine dominance, where hegemonic masculinities (Connell, 1995) struggle to maintain supremacy. First, disputes over the spatial definition of femicide reveal the blurry lines that distinguish between public and private spheres, how these boundaries have been tossed asunder by neoliberal markets and mass-mediated culture, and how the terms can be discursively manipulated through political power-plays. Second, the prohibition, consequent reinstatement, and final enshrining of mediation in Law 779 proves that, in the legal discourse and in judicial practice, women are objects of power-knowledge who continue to be intervened upon and scrutinized rather than protected by the State. In other words, the strong resistance to acknowledging women's substantive rights, to seeing women as inviolable and valuable independent of their normative gender roles, is a reactionary stance propelled by the Catholic Church and accepted by Daniel Ortega's State to legally consecrate the status quo of masculine authority.

Proof of this trend came in July 2014 with Daniel Ortega's issue of Presidential decree 42, which unilaterally reverses Law 779's spirit. The decree annuls the law's recognition of women's rights as collective rights and its attempt to legislate women's substantive right to a life free from violence. As I discuss below, while the original text of the law prohibited mediation-a form of judicially or police mediated dialogue between the woman filing a police report and her aggressor-Ortega's Regulation of Law 779 mandates that women reporting gender violence or intrafamiliar abuse are obligated to go through a process of mediation with the Family Counsels, community based organizations run by the Ministry of the Family, Adolescence, and Childhood composed of volunteers, judicial facilitators, family pastors, and religious leaders, before she can report her case to the Women and Children's Police Stations (6265). ${ }^{2}$ That is to say, the Regulation to the law establishes the family and

2 There seems to be serious confusion in journalistic reporting and social debates over whether passage through the "Consejerías de la Familia" is obligatory or not. But the language of the Regulation does read "When at the community level the situations provoking the couple or family conflicts are not solved ...women will have the option of going to the Women and Children's Police Stations" (6265, emphasis mine). The confusion arises in the interpretation of the law, since the 2013 Reform to the Law and the 2014 Regulations of the Law gut and reverse the original language and create these new community based institutions. See "Destacan necesidad de Reforma a Reglamento de Ley 779”, http://canal4.com.ni/destacan-necesidad-de-reforma-areglamento-de-ley-779/. 
masculine authority, rather than women as individuals, as the "social good to be protected at all costs” (Barragán, 2007, p. 15). Make no mistake, mediation poses a grave danger to women. In the Parliamentary debates for Law 779, Supreme Court President Alba Ramos cites the prevalence of femicide victims who had previously filed a police report yet were killed regardless ("Debates Parlamentarios" unpaged). ${ }^{3}$ According to the Autonomous Women's Movement (Movimiento Autónomo de Mujeres) in Nicaragua, the Regulations are illegal and constitute a plan of "social control and institutionalized gender violence" (Movimiento Autónomo de Mujeres de Nicaragua, 2014).

The legalistic discourse, especially when subject to such continual executive manipulation, can be seen as a series of changing rhetorical gestures in a societywide conversation that, at intervals, acknowledges or disavows femicide as a collective problem of public health. These discursive shifts are founded on coetaneous political interests or respond to increased social outcry and controversy. The story of feminist activism in the past 30 years of Nicaraguan history shows how social and legislative campaigns have changed the discursive terms of the game. The succession from a long-standing refusal to acknowledge intrafamiliar violence as a social-collective problem, to Law 779's broad-based feminist definition of femicide as public and private violence, to Ortega's restriction of femicide to interpersonal, romantic relationships, reveals extreme transformation, but also the highly conflictive and charged nature of gender relations. While we can critique the Ortega regime's reactionary stance and vested interest in riding each current wave of public opinion, the more pressing question is how will his short-circuiting of the law reverberate in the already fraught judicial terrain that victims of violence must traverse in order to seek protection? And, even more importantly, how many more women will have to die before the State takes responsibility for violent masculinities as a dilemma of women's human rights and general public health?

In light of the drastic reversal of Law 779 , we can see that the manner in which femininities are visible to the State is paradoxical at best. The story of Liseth, along with the hundreds of cases like hers that have appeared in recent years, betrays the bewildering way in which female sexuality is constantly policed by individual masculinities, while, at the same time, these women seem to exist at the blind spot of the State's eye. That women are the object of constant relational surveillance and intervention by husbands and partners is admittedly a difficult reality to take on through legislative and judicial reform. On the other hand, when women do enter the State's terrain to file a report, they are equally subject to scrutiny. They enter a complex procedural terrain in which the burden of proof and endurance still falls on their heads: the institutional procedures for filing a police report, the arduous process of following through with a case, the possibility of mediation, surveillance, and over-representation in the media, are all constant threats. These all represent institutionalized forms of re-victimization. But despite the invasive and dehumanizing intervention of the State, even when they have bravely passed through the process of filing a complaint, they still run the risk of being killed by their aggressor. Due to these failures and gaps in law enforcement and judicial procedures, Law 779 was

3 From here on, I cite the Parliamentary debates as "DP." 
already hard-pressed to stop gender violence or femicide. But it was a step in the right direction.

Ultimately, as can be gleaned from above, it is extremely difficult to establish a clear model of legislative reform stemming from a feminist philosophy that can be concretely enacted in the terrain of the political. We are discussing State-centered approaches, a problematic equation for feminists in light of State complicity with masculinities in Latin America, as I explore below. In addition, a rights-based or punitive-based strategy for the policing of gendered violence pre-supposes traditional victim-aggressor dynamics, as well as gender categories. As Rosa-Linda Fregoso pointed out, "When we focus only on the judicial sphere, we empower the state to keep ideologizing and controlling" (R. L. Fregoso, personal communication, June 27, 2014). Cautiousness about the State as a source of protection for women doubles in light of neoliberal socio-political formations in which crime control scenarios feed the furnaces of mass-incarceration, further dehumanizing and criminalizing those who dehumanized others.

Watching Ortega's political maneuverings in the context of region-wide trends towards mano dura policies of social control reveals a strange narrative twist. Due to the recent international labeling of Nicaragua as one of the safer countries among the violence-ridden Central American nations, rather than cracking down on gender violence, his government seems to be playing a statistical game. That is to say, that some feminists allege that Ortega released his Regulation of Law 779, which narrows the definition of femicide to those murders of women committed in the context of interpersonal relations, in order to maintain the appearance of gender non-discrimination and safety for women. ${ }^{4}$ Narrowing the legal definition of femicide certainly brightens up the numbers in support of Nicaragua's international standing on women's rights (Montenegro, 2014, unpaged). ${ }^{5}$ All of this sheds light on the paradoxical nature of legislative reform in the era of neoliberal policies, in which nation states must continue to project the image of compliance with international standards of human rights, despite declining standards of living that further foment violence and social fragmentation.

Even the original push towards recognizing gender violence as a public health and human rights problem in Nicaragua has been framed by punitively focused strategies for deterrence. The law certainly intended to inaugurate a new culture of punishment around gender violence. This approach can perhaps be justified in light of the historical impunity that has existed around crimes of gender violence. As I explore in the following chapters, however, carceral and punishment based strategies for stopping gender violence often go hand in hand with neoliberal strategies of social control that criminalize and individualize what is indeed a collective, systemic

4 According to the President of the Movement for Sandinista Renovation (Movimiento Renovador Sandinista - MRS), Ana Margarita Vijil Gurdián, "Es importante que haya leyes favorables a las mujeres, pero sería realmente importante si viviéramos en un país en el que las leyes se cumplen y no son solamente palabrería y demagogia para la exportación” (unpaged) (ND, 2014b).

5 In October 2014, the International Monetary Fund released its report on which countries have the smallest gap of inequality between the genders. Nicaragua placed $6^{\text {th }}$ in the world, only behind several Scandinavian countries, angering many feminists and opposition leaders who claim that these numbers do not take into account quality of life and freedom from violence. 
crisis. For this reason, my analysis of legal interventions into the cultural realm problematizes the facile categorization of 'good men' and 'bad men' that these punitive strategies entail, and additionally questions equations for social change or solutions for ending impunity that further polarize and exacerbate tensions in gender relations. Feminist scholars such as Kristin Bumiller $(1987,1988)$ and Elizabeth Bernstein (2010) wrote about the cooptation of feminist agendas against gender violence by neoliberal dynamics. Often, as they discussed, the international human rights discourse of global NGOs disguises and reinforces neocolonial social relations and fierce neoliberal crime-control strategies, instituting "feminism as crime control across the globe" (Bernstein, 2010, p. 57).

The public debate around this legislation reveals the weighty symbolic repercussions of its proscriptions for Nicaraguan society. The mere fact of introducing feminist theoretical concepts-such as femicidio, femicida-into the legal document and the local vernacular reveals a social impetus towards reexamining collective notions around gender violence. ${ }^{6}$ The debates about these new concepts in the Nicaraguan cultural scene have been fraught with conflict, revealing the terrain of gender relations as a rocky one in which serious challenges to old norms are afoot. These new terminologies and conceptualizations certainly hit a sore spot. Not only does the passing of the law point towards evolving societal conceptions in regards to what has historically been considered legitimate violence. It also reveals that feminist efforts to discursively intervene to politicize violence-in couples, the family, and public spaces-are taking effect and gaining credence in Nicaraguan society. As Argentina Espinoza, a Specialist in Public Health in Nicaragua, claims, "We have an opportunity with the Integral Law that begins with recognizing that violence is a grave problem of human rights and public health."”

\section{Gender violence and the law}

From the vantage point of women's legal status in Latin America since colonial times, it is not difficult to argue that the law has been an instrument of violence. As Barragán (2005b) effectively argued, the independent nation states of Latin America enshrined colonial customs of racial, ethnic, and gender discrimination into their newly minted constitutions and penal codes, relying on concepts such as honor and infamy to maintain existing hierarchies (pp. 68-69). Patria potestad indeed entered most Latin American constitutions as the form of tutelage under which women, their bodies, and their property were subject to the complete control of fathers, husbands, or brothers. Patria potestad, according to Barragán (2005a), constitutes

6 See theoretical and legal definition of femicide below. The term femicida has been used in the press since mid-2012 to describe men who kill women, whether husbands, ex-partners, or acquaintances. From a feminist standpoint, it describes someone who commits a hate-crime by killing a woman because she is a woman, in the context of the unequal power relations between men and women. Only recently with President Daniel Ortega's presidential Regulations to Law 779 has the press reverted to the terms parricide and parricida in a majority of cases that would have been previously typified as femicide.

7 This and all translations that follow are mine. "Neutralizar violencia intrafamiliar desde barrios" 29 March 2012. http://www.elnuevodiario.com.ni/nacionales/246561. 
"...the power invested in the patriarch... and defines this power, or potestas, as the command of the lord over his serfs, the power of the King over his subjects, and the authority of the father over his children and lineage" (p. 31). This history of subjugation undoubtedly colors the hesitance with which feminist groups appeal to the State for protection.

With the advent of international human rights treaties and conventions, however, women's groups found new legal footing to stand on, specifically in the battle against gender violence. The creation of the International Criminal Court by the United Nations Security Council in 1993, as a means to judge crimes committed in the Bosnia-Herzegovina conflict, marks the first time that rape is recognized internationally as a war crime and a serious infringement of women's rights (Masson, 1999, p. 63). The International Criminal Court and its recognition of rape indicate global changes occurring in international law, due largely in part to the expansion of women's movements across the world in the 1990s. The creation of international conventions such as the Convention to Eliminate all Forms of Discrimination Against Women (CEDAW) and the Inter-American Convention on the Prevention, Punishment, and Erradication of Violence Against Women (Convention Belem do Pará) created international legal frameworks that sought to amend the formal equality of national laws that in fact harbored de facto inequality.

But feminist scholars of jurisprudence, such as Catherine MacKinnon (2006) and Inderpal Grewal (2005), offered salient criticisms of the human rights paradigm and international law as well, for varying reasons. With the virtual dissolution of the State and the rise of multinational corporations, organized criminality, and religious fundamentalisms, MacKinnon (2006) rightly wondered if international law offers hope or if "...male dominance [is] equally present in and transmuting into transnational forms?" (p. 4). I would affirm the fallibility of the law, whether international or national, in light of the new transnational forces that MacKinnon mentions. As I believe Sayak Valencia (2010) would argue through her concept of gore capitalism, legalistic frameworks are some of the faltering humanistic discourses that fail to ameliorate or address the violent realities of neoliberalism. Valencia points out that not only have "all of the economic taboos and of respect for life [...] been broken," but additionally neoliberalism doesn't know how to propose any model of social integration (pp. 50, 81). As these developments suggest, it may be hard to imagine international law having the necessary clout to counter mutating group alliances and their nefarious effects on women's safety across the globe.

What we're talking about here are group alliances that transcend national boundaries and party politics. Therefore, as I will argue throughout this project, along with Lauren Berlant and MacKinnon, the public-private distinction still constitutes a theoretical quagmire for feminist scholars. It is a distinction that Lauren Berlant (2000), following Jürgen Habermas, suggested was no more than a "Victorian fantasy," which became entrenched in political theory and medical and criminological discourse (p. 3). ${ }^{8}$ Indeed, even in international human rights law the

8 Berlant draws from Habermas's 1989, The Structural Transformation of the Public Sphere: An Inquiry into a Category of Bourgeois Society. Trans. Thomas Burger and Frederick Lawrence. Cambridge, Mass. 
public-private distinction permeates legal frameworks. According to MacKinnon, the human rights generations laid out in the Universal Declaration of Human Rights hierarchize political and civil rights (first generation rights) above social and economic rights (second generation rights), with those in turn placed above group or collective rights (third generation rights) (p. 5). As MacKinnon argues, however, women experience this hierarchy in reverse. Without fundamental social and economic rights, women have found political and civil rights to be largely superficial or ineffective. This means that group rights are the real "first generation" rights concern for women: "Women are men's unequals as groups. Real equality rights are collective in the sense of being group-based in their essential nature. Individuals may suffer discrimination one at a time, but the basis for the injury is group membership" (p.5).

So this calls for a re-thinking of the idea of group based power. MacKinnon helps us understand how women's rights are collective rights. But, going further, we can see how certain groups outside of the State in Nicaragua were powerful enough to derail Law 779, to short circuit a socio-legal recognition of women's collective rights. The Catholic Church constitutes the main block of power and harbors the main group-based affinity that could dissuade Nicaraguan publics from accepting the law. However, the fact that President Ortega has tightened his alliance with the Catholic Church in recent years is quite well known. ${ }^{9}$ Between their control over the Church and traditional political power, I believe that certain masculinities sincerely do not want to give women, as a group, a share of power. For this reason, the acknowledgement of women's collective rights in Law 779 was considered so threatening. This is what Celia Amorós (1990) called "patriarchal pacts", those alliances across social and economic classes that cement men's dominance. As I explore below, the fear of having to share power was already prevalent at the time the National Assembly first passed Law 779. Indeed, this impasse signaled the death of Law 779 in Nicaragua.

\section{Networks of resistance: The road to Law 779}

As part of the ground gained by feminist movements across Latin America in the last two decades, Nicaragua passed a national law against gender violence that went into effect in June 2012. The Integral Law Against Violence Towards Women, Law 779, codifies femicide, as well as violations to women's physical, sexual, psychological, and patrimonial integrity, into the Penal Code as criminal offenses, outlining the corresponding punishments. In addition, the law adds media, labor, and institutional violence as criminal offenses. Law 779 also created the District Tribunals Specializing in Violence (Juzgados de Distrito Especializados en Violencia) and the National Inter-institutional Commission Against Violence Towards Women (Comisión Nacional Interinstitucional de Lucha contra la Violencia hacia la Mujer). In its Article 46, Law 779 prohibited mediation: the long-standing institutional practice of

9 As evidenced by the Sandinista slogan: "Nicaragua: Christian, socialist, and solidary" [Nicaragua: Cristiana, socialista y solidaria]. 
police or judicial agents facilitating a dialogue between the aggressor and the accuser to bypass legal sanctions. The prohibition in the original body of Law 779 attempts to halt this practice, due to the fact that judicial officials have often privileged the preservation of the family unit over the physical safety and integrity of individual victims of violence. All of these elements make Law 779 a groundbreaking piece of legislation that tackles the asymmetrical power relations between men and women through specific prohibitions and creative institutional innovation.

The term femicide first circulated through Anglophone academic circles through the work of Jane Caputi and Diane Russell (1992), who claimed that "femicide" is "the mysoginist killing of women by men, [and] is a form of sexual violence" (p. 13). The term feminicidio was used by Latin American feminist activists in the Dominican Republic in the 1980s and introduced to academia by Marcela Lagarde in 1987 (Fregoso \& Bejarano, 2010, p. 4). Rosa-Linda Fregoso, Cynthia Bejarano, and Marcela Lagarde y de los Ríos (2010) used the term feminicidio to encompass various dimensions: first, feminicide is defined as "the murders of women and girls founded on a gender power structure" (p. 5). Second, feminicide is gender-based violence that is both public and private, indicating the complicity of the State and of individual perpetrators, thus encompassing "systematic, widespread, and everyday interpersonal violence" (p. 5). Finally, it is a "systemic violence rooted in social, political, economic, and cultural inequalities" (p. 5). ${ }^{10}$ These theoretical advances towards conceptualizing the murder of women continue to be debated and have wide-ranging consequences in national and international contexts.

Law 779 indeed carries out a radical legal gesture akin to those of contemporary laws being passed against gender violence in Mexico, Guatemala, Costa Rica, Spain, and other Latin American countries that also codify femicide or feminicide. ${ }^{11}$ According to Montenegro, Jiménez Martínez, Mejía Palma, Chow Cruz, and Quirós Vísquez (2014), "The law known as Law 779 is the legal instrument with the most history in the women's movement in Nicaragua. Its necessity, its origins, and its content condense 30 years of struggle of at least two generations of Nicaraguan women" (p. 2). It is fundamentally a legal codification of feminist theoretical principles, as evidenced by the preamble and Article 1, the object, sphere and policy of Law 779:

The present law has as its objective to act against the violence that is exercised against women, with the purpose of protecting the human rights of women and guaranteeing them a life free from violence, which favors their development and well-being according to the principles of equality and non-discrimination; establishing integral measures of protection in order to prevent, punish, and eradicate violence and lend assistance to women

10 "In this sense, the focus of our analysis is not just on gender but also on the intersection of gender dynamics with the cruelties of racism and economic injustices in local as well as global contexts" (Fregoso \& Bejarano, 2010, p. 5).

11 In the Parliamentary debates, the representatives use femicide and feminicide interchangeably. I did not find a specific instance in the debates where they justified the use of femicide in the final law. 
Encuentro №. 100, 6-37, 2014

victims of violence, driving for changes in socio-cultural and patriarchal patterns that support power relations. ${ }^{12}$

The Nicaraguan national law, much like the Mexican law, is innovative in its acknowledgement of the structural, systemic, and collective dimensions of violence against women. These laws came about as a result of extensive campaigning on the part of feminist organizations in both countries. Given that the majority of Latin American countries had ratified international accords that addressed violence against women such as CEDAW and the Convention Belem do Pará, feminist groups began to demand that governments uphold their commitment to the tenets of these international agreements (Fregoso \& Bejarano, 2010, p. 18).

Notably, the language of Law 779 is modeled on that of the Convention of Belem do Pará, whose rhetorical bent frames gender violence as a fundamental obstacle to women's full participation as citizens, to the "free and full exercise of her civil, political, economic, social and cultural rights" (Article 5). While Article 1 of Belem do Pará defines violence against women as "any act or conduct, based on gender, which causes death or physical, sexual, or psychological harm or suffering to women, whether in the public or private sphere," the preamble establishes that "violence against women is an offense against human dignity and a manifestation of the historically unequal power relations between women and men." The inclusion of symbolic and educational non-discrimination is also significant. Article 6 affirms "the right of women to be valued and educated free of stereotyped patterns of behavior and social and cultural practices based on concepts of inferiority or subordination." ${ }^{13}$ Belem do Pará and the national laws modeled on it set a precedent acknowledging that gender inequality is false and detrimental to women's ability to develop as full, autonomous beings. In the words of Catherine MacKinnon, commenting on the Convention, "This is what a substantive equality approach with the necessary substance looks like" (2006, p. 9).

The story of how Law 779 came to be passed in Nicaragua begins in the 1980s, when AMNLAE (Asociación de Mujeres Nicaragüenses "Luisa Amanda Espinoza"), the feminist organization within the Sandinista Front for National Liberation (FSLN), formed the Women's Houses [Casas de la Mujer], which offered healthrelated, psychological, and legal services, as well as helpful workshops on sexuality, contraception, and professional training (Kampwirth, 2004, p. 203). At this time, AMNLAE and other women's groups and collectives began to include violence against women in their political agenda, offering legal support and medical and psychological attention (D’Angelo, Molina \& Jubb, 2008, p. 12). In 1983, AMNLAE opened the Woman's Legal Office (Oficina Legal de la Mujer) to aid women and children living in violent situations, establishing coordination with the National

12 "La presente Ley tiene por objeto actuar contra la violencia que se ejerce hacia las mujeres, con el propósito de proteger los derechos humanos de las mujeres y garantizarles una vida libre de violencia, que favorezca su desarrollo y bienestar conforme a los principios de igualdad y no discriminación; establecer medidas de protección integral para prevenir, sancionar y erradicar la violencia y prestar asistencia a las mujeres víctimas de violencia, impulsando cambios en los patrones socioculturales y patriarcales que sostienen las relaciones de poder" (1362).

13 See the English translation of the Convention at http://www.oas.org/en/mesecvi/convention. asp. 
Police and gradually opening offices all across the country (D'Angelo et al., 2008, p. 12).

In the 1990s, after the Sandinista electoral defeat, AMNLAE, the major feminist organization associated with the FSLN, broke free of party control and, alongside other pre-existing and newly founded feminist groups, began to organize and form autonomous collectives (Montenegro, 1997; Kampwirth, 2004; Babb, 2001). During this time period many feminist groups sprang up across the country, participated in international summits, and came to be integrated into nationally organized "Redes," or networks (Blandón Gadea, 2011, p. 39). The organization of the feminist organizations into a loose collection of networks took place in 1992 at the Women's Meeting "Diverse but United” held as a national feminist congress in Nicaragua (Puntos de Encuentro). ${ }^{14}$ As strong evidence of the groundwork laid by feminists in the 1980s, the participants in a workshop on violence at the congress were ready to lay out an agenda with five concrete steps towards ending violence:

...that rape laws should be changed to make rape a public, rather than private, crime; that the penal code be reformed to defend women; that educational and media campaigns be launched; that a women's network against violence be formed; and that the public schools begin teaching sex education (Cuadra, Fernández \& Úbeda, quoted in Kampwirth, 2004, p. 63)

Indeed, not long after, all but one of these steps was under way, according to Kampwirth (p. 63).

In line with the agenda set by the participants in the violence workshop, at the conference "Diverse but United" the longest lasting and most influential of the women's networks was founded: the Network of Women Against Violence (Red de Mujeres Contra la Violencia, henceforth RMCV). The RMCV incorporates activists from NGOs, government ministries, and autonomous feminist organizations to form a powerful coalition. The RMCV has wielded its influential, forceful voice against violence and impunity through the media and through mass organized protests since it was founded in 1992. Moreover, the RMCV, along with Catholic women for the Right to Decide (Católicas por el Derecho a Decidir), is considered one of the few accurate sources for statistical information on gender violence, since the National Police's count has often been colored by the lack of proper indicators of gender violence or by political motives for concealing this violence. ${ }^{15}$ The broad-based organization of the RMCV has allowed for the continuous presence of feminist activists in the streets of major Nicaraguan cities, keeping the issue of gender violence visible and present in public debates.

14 See Kampwirth's (2004) chapter "Reacting to Revolution in Nicaragua: Feminist and Antifeminist Politics in Post-Sandinista Nicaragua."

15 During the Parliamentary debates for Law 779, National Assembly Representative Wilfredo Navarro Moreira cites the RMCV for statistical information of femicide: "La escasa información disponible en Nicaragua incluye datos de la Red de Mujeres Contra la Violencia (RMCV), que contabilizan 79 mujeres asesinadas durante el año 2009 y en el primer trimestre de 2010, 12 mujeres -entre ellas 4 niñas menores de 6 años que fueron asesinadas con premeditación y en forma atroz, a manera de venganza contra las madres de las victimas". See: http://www.asamblea.gob.ni/trabajo-legislativo/diario-de-debates/. 
Encuentro No. 100, 6-37, 2014

These trends form part of a region-wide feminist movement against gender violence that took root in the past two decades. According to Monserrat Sagot (2012), the Central American Feminist Network against Violence Towards Women (la Red Feminista Centroamericana contra la Violencia hacia las Mujeres) and many other organizations have movilized in the last two decades in the face of what she calls "the scandalous rise in the region of all forms of violence against women, including femicides" (p. 80). Inasmuch as it constitutes part of the struggle to establish the cultural meanings of gender relations and gender violence, Sagot confirmed that Central American feminisms have been able to make visibile and typify sexual violence, defining it as a systematic and citizenship problem, not a private or a family issue (p. 85). Sagot's claim is affirmed by Montenegro in the case of Nicaragua, where she asserts that Law 779 is the culmination of a vindication that women began to demand just as soon as the first women's centers "managed to place in the public space the problem of violence that people experienced in the interior of their homes, a reality that had remained hidden, concealed, silenced" (Montenegro et al., 2014, p. 2).

Along with the work of the feminist organizations, and due to their mobilizations, Nicaraguan institutions have also evolved to address gender violence. In 1995, the RMCV carried out a national campaign for the passing of Law 230, ratified by the National Assembly in $1996 .{ }^{16}$ Law 230, for Reform and Addition to the Penal code to Prevent and Sanction Intrafamiliar Violence, implemented specific protective procedures in cases of violence against women and children. ${ }^{17}$ In 1996, the RMCV in Nicaragua was involved in negotiating with the National Police for the creation and proper operating of the Women and Children's Police Stations [Comisaría de la Mujer y la Niñez] (D’Angelo et. al, 2008, p. 14). In reality, the Women and Children's Police Stations were an accomplishment acheived by a new "crosspartisan, cross-class alliance for gender justice" composed of Sandinista feminists and right-wing women's groups, who together helped create these women-staffed police stations where women could go report abuse without fear of re-victimization (Kampwirth, 2004, p. 67).

The following year, the RMCV, the Supreme Court, and the Nicaraguan Women's Institute carried out an evaluation of the application of Law 230 all over the country, finding that the legal framework was insuffiencient for various reasons: many women experienced violence from intimate partners, many experienced economic or social violence that prevented them from studying or working, and others had husbands or partners that stole their salary or personal goods; Law 230 didn't tackle any of these problems (Montenegro et al., 2014, p. 3). These evaluations demonstrated the validity of the feminists' demands for a special and integral law against violence.

Towards the end of the 1990s a public scandal emerged that would have extensive ramifications for the movement against sexual violence. As an emblematic

16 Consult the web page of the NGO "Puntos de Encuentro": http://www.puntos.org.ni/index.php/ es/red-de-mujeres-boletina49.

17 The Law can be downloaded at: http://www.hsph.harvard.edu/population/domesticviolence/ nicaragua.dv.96.pdf. 
example of overcoming seemingly insurmountable obstacles to denouncing sexual abuse, in 1998 Zoilamérica Narváez, the step-daughter of former President and Sandinista leader Daniel Ortega, publicly denounced that she had been sexually abused by her step-father since childhood. Without entering into the details of the case, which have been explored extensively by feminist thinkers, ${ }^{18}$ we can highlight the symbolic significance of the case for feminist organizers in the struggle against gender violence. According to one of the most influential voices in Nicaraguan feminism, RMCV leader María Teresa Blandón Gadea (2011), Zoilamérica's case "obliged us to recover from the personal crises the case generated, rethink politicalaffective adhesions, reflect, debate, and keep fighting for all the women in similar situations to that denounced by Zoilamérica" (p. 65). Furthermore, in the study that Blandón conducted of feminist movement leaders, she reports that all her interviewees cited the case as formative for the movement due to the courage of Zoilamérica to break the silence. She explains that it also revealed the mechanisms used by masculinities to mobilize symbolic authority:

the power granted by the father role, political recognition or age... the power of masculine complicity that puts the gender interests of men above their political differences, [and] the real power of men, aside from the symbolic, that allows them to evade the law and remain unpunished (Blandón Gadea, 2011, pp. 65-66).

These elements of masculine privilege that the case brought to light continue to be relevant to the controversy over Law 779 and mediation, in the sense that they touch the prestige of the father and contribute to dismanteling the myth of his protection over of the nuclear family in the Nicaraguan imaginary. I will revisit these mechanisms of symbolic authority below.

The RMCV's involvement in the Women and Children's Police Stations in the years follwing the 1997 evaluation of the legal framework included pushing for the erradication of a form of mediation called "extra-judicial arrangements," where in cases of intrafamiliar violence, women had to sign a form and assume part of the responsiblity for the violence and abandon their right to a trial (D'Angelo et al., 2008, p. 14). Almost 20 years later, in 2014, the prohibition of mediation has constituted the most controversial part of Law 779, as I will discuss below, provoking accusations on the part of conservative sectors and the Catholic Church that the law threatens the institution of the family. ${ }^{19}$ In the early 2000s, the RMCV continued campaigning for legislative and educational change. As part of this struggle, the 2008 Reform to the Penal Code established "intrafamiliar violence" as a specific crime understood to mean "physical or emotional damage," punishable with 2 to 13 years in jail, depending on the seriousness of the injuries (D'Angelo et al., 2008, p.18).

18 See Sofía Montenegro (1999); also Delphine Lacombe (2010).

19 En septiembre de 2013 se aprobó una reforma a la Ley 779 que permite la 'mediación con excepción'. Según la diputada Irma Dávila, esta reforma estipula que se puede recurrir a la mediación si 1) el agresor no tiene ningún antecedente; 2) se ha obtenido una constancia del juez de lo antes señalado. Además, sólo se puede mediar una vez y nunca se le puede imponer a una mujer que no desee mediar (Carranza Mena \& Lara, 2013). 
Encuentro №. 100, 6-37, 2014

The draft bill of Law 779 sprang from the work of two separate commissions who elaborated separate draft bills for the law in 2011. The first came about as a result of the National Assembly's "Concerted Economic Agenda from Nicaraguan Women," presented in January 2010, which demanded that "spaces for citizen participation and the laws that protect women's rights be made effective, for the exercise of their citizenship." The Agenda also asked for the implementation of "public policies that take on crucial topics like non violence against women." 20 Based on this agenda, the Movement of Women Workers and Unemployed "María Elena Cuadra" and 19 other governmental and civil society organizations got together and wrote a draft bill based on their study of legislation against gender violence in Costa Rica, El Salvador, Spain, Guatemala, Honduras, México, the Dominican Republic, and Venezuela. ${ }^{21}$

Additionally, in mid 2011 an inter-institutional team of legislators, members of the judiciary, public officials, police, and representatives of the Nicaraguan Women's Institute formed the Commission of Study and Reforms of Crimes of Violence against Women, counting on the assistance of lawyers from the Women and Children's Police Stations, public defenders, psychologists, and doctors form the Institute of Legal Medicine. Over some 22 working sessions they studied legislative models from all over Central America, as well as international conventions such as CEDAW and the Convention of Belem do Pará. During the presentation of the draft bill in the National Assembly, Secretary Alba Palacios Benavidez noted that the laws across Central America vary between 1) partial reforms of penal law (Nicaragua, Panama); and 2) a set of norms that form precautionary laws of a mixed nature against the repetition of violence implementing concise, expedited judicial procedures (Costa Rica, Honduras, El Salvador, Guatemala). All of these laws set up specialized tribunals for processing domestic violence cases. Palacios affirms that while none of this legislation resolves the deeper problem behind gender violence, the objective of all the laws is the protection of life and protection of the physical, emotional, sexual, and patrimonial integrity of women, in accordance with the norms established in Belem do Pará. (“DP”, unpaged).

Going on to argue for the necessity of an integral law, Palacios explains that judicial practices in these countries have been applied in a biased fashion, given that:

20 Parliamentary debates for Law 779: "hagan efectivos los espacios de participación ciudadana y, las leyes que protegen los derechos de las mujeres para el ejercicio de su ciudadanía...". Asimismo la implementación de "politicas públicas que aborden temas cruciales como"... "la no violencia contra las mujeres."

21 The other organizations included: Secretaría de la Mujer (FENACOOP R.L), Congreso permanente de Mujeres Empresarias de Nicaragua (CPMEN), Federación de Mujeres Productoras del Campo de Nicaragua (FEMUPROCAN), Voces Caribeñas, Comité Nacional de Mujeres sindicalistas de Nicaragua (CNMSN), Foro de Mujeres para la Integración Centroamericana (FMICA), Fundación Mujer y Desarrollo Económico Comunitario (FUMDEC), Secretaría de la Mujer de la Central de Cooperativas de Servicios Múltiples (PRODECCOP R.L), Red de Mujeres Chontaleñas, Secretaría de la Mujer de la Unión Nacional de Agricultores y Ganaderos (SMUNAG), Las Gaviotas(ASOMUPRO), Fundación para la Promoción y Desarrollo de las Mujeres y la Niñez "Blanca Aráuz" (FUNDEMUNI), el Consejo de Mujeres de Occidente (CMO), Colectivo de Mujeres Itza, Asociación de Mujeres para la Integración de la Familia (AMIFANIC), Instituto de Liderazgo de Las Segovias, Mesa por la Equidad de Género Nicaragua y Coordinadora de Mujeres Rurales. 
...the measures of protection, security, and prevention established by these laws are frequently breached by the aggressor, and the State doesn't have effective mechanisms for compliance. On many occasions, procedural formalisms impede the persecution of aggressors and generate impunity...

The penal process is impregnated with symbolisms and guarantees that on some occasions they are turned upon the victims of domestic violence, where the evacuation of evidence goes more towards protecting the rights of the accused than those of the victim... In penal law only the facts and legal precepts are considered relevant in order to determine the case, it doesn't take into account emotions, fears, or relations of power implicit in violence against women ("DP", unpaged)

Palacios points out how the ingrained inequalities in judicial practice that stem from the androcentric framework of law and the shortcomings of "formal equality" have fostered impunity in Central America. For these reasons, Palacios argues for the incorporation into Nicaraguan law of a human rights and anti-discrimination framework based on the non-neutrality of the protected subject, "breaking with the family-ist vision [vision familista] and the supposed neutrality of norms" in order to create true substantive legal equality for women ("DP", unpaged).

During the debates, legislators and judiciary members also presented arguments as to why the existing legal framework was insufficient. President Justice of the Supreme Court Alba Ramos affirmed that, although the reformed Penal Code (2008) codifies intrafamiliar violence, it establishes the penal figure based on the outcome only, punishing those crimes that cause an injury or damage. Furthermore, patrimonial violence, i.e. the extraction or destruction of the victim's personal belongings, and femicide are excluded from the Penal Code. For these reasons, Ramos concludes that the Penal Code does not establish an adequate penalization of the "diverse manifestations of violence against women, that are produced in the private sphere, as well as the public" ("DP”, unpaged).

The following is a brief outline of the findings [dictamen] on Law 779, resulting from the combined recommendations of the two commissions that worked on a draft bill for Law 779, presented by Representative María Dolores Alemán Cardenal, the President of the National Assembly's Commission of Women, Youth, Children, and Family Issues. The law's objective is to prevent, assist, sanction, and eradicate violence against women as a manifestation of discrimination, the situation of inequality, and the power relations that men exercise in any of their forms or places. The bill affirms that violence, in addition to being a public health problem, is a problem of citizen security, obliging the Nicaraguan State to act to protect women's human rights. Its governing principals include the following: Non-discrimination, Non-violence, Due diligence on the part of the State, Celerity, Indemnification, No secondary victimization, Protection for the victims, Concentration, Publicizing, Completeness and the Principle of Inter-institutional Coordination. The bill establishes the Nicaraguan Constitution, its laws, CEDAW, and the Convention of Belem do Pará as its sources of interpretation. The bill mandates the installation of tribunals specializing in violence that include a Specialized Courtroom for violence 
in the Court of Managua, as well as a female magistrate trained in violence in each of the country's regional courts. Feminicide was codified as a penal type, committed when a man kills a woman as a result of extreme violence in the public or private sphere. The law adds a new chapter to the Penal code that codifies the following crimes: physical, psychological, patrimonial, and economic violence, intimidation or threats against women, child abductions, violence in the workplace, violence against public functions of women, failure to denounce, and obligation to denounce sexual abuse. In addition, the bill establishes procedures for the judgment of these crimes and affirms the inadmissibility of mediation. It also creates the National Interinstitutional Commission of Struggle against Violence towards Women. Finally, it creates the policy to prevent, assist, and protect women who experience violence that includes the participation of Non-governmental organizations, with the goal of getting suggestions from those groups that specialize in the topic of violence against women ("DP", unpaged).

After the presentation of these findings on Law 779, the National Assembly members debated the approval of the general outline of the law. Prominent representatives, such as co-author of its introduction, Wilfredo Navarro Moreira, vigorously supported the call for the codification of femicide/feminicide: "... [because it] tackle[s] violence against women in a specific manner, abandoning neutralizing expressions like domestic violence or family violence" (Navarro Moreira, "DP", unpaged, emphasis mine). Some of the highlights of the representatives' speeches included just these types of assertions: that violence against women is a public, not just private, issue, one of both health and security; that power relations should be equaled out between men and women; that instances of femicide seem to be rising in an alarming fashion; and that there is a pressing need for inter-institutional coordination and a society-wide effort to stop the violence.

The triumphal and emphatic tone of the representatives' comments disembarks into a unanimous approval of the general outline of the law. All of the representatives who took the floor acknowledged the necessity for this law in Nicaragua, with many affirming that violence against women has been considered a private affair and the business of the family for far too long. Some, such as Martha Marina González, emphasized the law's significance as part of the historical struggle for women's rights and the FSLN's role in advancing these rights. Representative María Margarita López Blandón affirmed, "The Sandinista Front since its birth has come along championing, leading the struggle in favor of women. Thanks to the revolution women came out into public life" ("DP", unpaged). Despite some partisan remarks, the Assembly truly came forth as a united front in favor of the law. Representative Irma Dávila Lazo exclaimed:

Nicaragua has a woman's name, the struggle has a woman's name, and justice has a woman's name. This is why we're here united, men and women, creating justice for the Nicaraguan woman, approving this law in consensus, a law that guarantees protection to women in all its forms and spheres ("DP", unpaged). ${ }^{22}$ 
Reading the debates, I perceive a spirited and united push towards expanding and protecting women's rights in Nicaraguan society. Not one opposing argument is offered, and, in fact, many representatives indicate that their initial hesitation towards the Law was overcome in the face of the commissions' findings.

However, some representatives demonstrate an acute awareness of accusations already circulating in the press and public opinion that the law is anti-male or attacks men. Indeed, those who mention it attempt to dispel this accusation. Representative Wilfredo Navarro commented that although many people in the media claim that the law is a persecution of men, "we men shouldn't fear the law, because this law is made to punish those that violate women's rights, those who disrespect those rights" ("DP", unpaged). Commenting on this fear, Representative Salvador Talavera Alaniz affirmed,

I know some male colleagues are afraid... that with this law from here on our women will probably have powerful weapons in their hands, and all the sudden they may even use them... probably someone could even try to believe that they could be unjustly used against some men... ("DP", unpaged).

The allusions to these fears refer us to a common discursive thread in thinking about gendered power relations in Nicaragua: men seem to conceive of feminism and women's rights as a war as a direct attack on their position in society. These concerns indicate a tendency towards polarized thinking that disallows the nuances of compromise or the possibility of shared power. Furthermore, they communicate various aspects of the tension implicit in the social debate about Law 779. First, these fears implicitly recognize the power imbalance that exists favoring masculine supremacy and feminine subordination. Second, they show an unwillingness to cede power to women. Finally, the reference to these fears foreshadows the sentiment that will eventually win out in official politics, leveling the advances made by Law 779 .

Law 779's original gesture (before the Reform and Regulation) was indicative of a monumental shift in the way women's rights were conceptualized in Nicaragua. One the one hand, the manner in which femicide was codified into the Penal Code signified a broad-based recognition of gender discrimination as collective in nature, and, consequently, acknowledged that women's rights are collective rights. Article 8 states that violence against women in any of its forms or areas (in the home or workplace): “...should be considered a manifestation of discrimination and inequality that women experience in power relations, recognized by the State as a problem of public health, citizens' security..." $(1364)^{23}$

22 Dávila was emphasizing the linguistic and symbolic connotations of the fact that the nouns Nicaragua, lucha, and justicia, are all feminine. "Nicaragua tiene nombre de mujer, la lucha tiene nombre de mujer, y la justicia tiene nombre de mujer."

23 Translation is mine. "La violencia contra la mujer en cualquier de sus formas y ámbito debe ser considerada una manifestación de discriminación y desigualdad que viven las mujeres en las relaciones de poder, reconocida por el Estado como un problema de salud pública, de seguridad ciudadana y en particular: a) misoginia, b) violencia física, c) violencia en el ejercicio de la función pública contra la mujer, d) violencia laboral contra las mujeres, e) violencia patrimonial y económica, f) violencia psicológica, g) violencia sexual" (1364). Article 8 also includes a description for each one of these forms of violence, which I've omitted here for the sake of space. 
Encuentro No. 100, 6-37, 2014

In regard to the definition of femicide given in the original law, Article 9 outlines a conception that, just like Article 8, recognizes discrimination against women as a group-based phenomenon grounded in power relations: "He commits the act of femicide the man who, in the context of the unequal power relations between men and women, kills a woman whether in the public or private sphere in any of the following circumstances..." (1364, emphasis mine). ${ }^{24}$ Though it may signify a challenge in procedural terms to conceive of individual instances of gender violence as collective and group based in nature, this is the type of discursive, rhetorical gesture that can signify the beginning of serious social transformation.

Rosa-Linda Fregoso refers to the law's ability to educate and influence society through the deployment of new terminologies and cultural models for conceptualizing social practices as the "norms changing potential" of the law (R. L. Fregoso, personal communication, June 27, 2014). This vision of the transformative power of the law places a heavy burden on civil society groups to mobilize the law and translate its tenets in a manner that will be decipherable and politically tenable. The existence of an active, autonomous feminist movement in Nicaragua, which has continued to develop since its initial years, surely allowed for the passing of such radical legislation. However, at the time the law passed there was indeed a broadbased acceptance of the law across society. An article in El Diario of Spain, reported that an opinion poll taken in April 2012 showed that $82 \%$ of Nicaraguans supported Law 779 (Fernández, 2013). Despite the increasing influence of the Catholic Church and other conservative sectors on President Daniel Ortega's mode of governance, he initially stood strongly behind Law 779. The question becomes, then, how could the National Assembly and the President completely change their stance over a period of two short years?

\section{Reform of Law 779, October 2013}

In the original body of Law 779, Under Title 6, Penal Procedures, Article 46 "Prohibition of mediation," states that: "Mediation will not proceed in the crimes signaled in the present law" (1372). That is to say that the article prohibited mediation in any of the instances of violence codified by the law, whether physical, emotional, patrimonial, or sexual. As a monumental reversal of what in fact was a common institutional practice, the prohibition of mediation provoked serious societal resistance. The opposition has gathered under the banner of the unity of the Nicaraguan family, claiming that the law "atenta contra la familia," literally "makes an assassination attempt on the life of the family." The Catholic Church and Evangelical churches, whose rhetorical classification of the law verged on hyperbolic and apocalyptic, led the charge against the law's reforms. The Bishop of Estelí, Juan Abelardo Mata, opened fire on Law 779 stating that, "The number of the beast is no longer 666, but rather 779, because it's destroying families” (Fernández, 2013). Taking their allegations even further, they claimed that the law openly attacked men

24 "Artículo 9: Comete el delito de femicidio el hombre que, en el marco de las relaciones desiguales de poder entre hombres y mujeres, diere muerte a una mujer ya sea en el ámbito público o privado, en cualquier de las siguientes circunstancias..." (1364) (Asamblea Nacional de Nicaragua, 2012). 
and that the jails were filling up due to women's frivolous complaints (Fernández, 2013).

At the beginning of October 2013, a little over a year since Law 779 had gone into effect, the National Assembly voted to amend Article 46, allowing for mediation in certain crimes codified by the law, with the approval of the Nicaraguan Supreme Court. When the Reform first came out, many media sources were reporting that mediation would be permitted in cases of felonies qualified as "less serious" [menos graves] (ND, 2013). However, the text of the Reform itself allows for mediation in nine out of the ten felonies established by the Law. It allows for mediation in the following crimes:

a) physical violence if it provokes light injuries; b) psychological violence if it provokes damage to her psychic integrity that requires psychotherapeutic treatment; c) patrimonial and economic violence, except for economic exploitation of women; d) intimidation or threats against women; e) child abductions; f) violence in the work place; g) violence against women in their public functions; h) failure to denounce; i) obligation to denounce an act of sexual abuse (Ley de Reforma y Adiciones a la Ley No. 779 Ley Integral Contra la Violencia Hacia las Mujeres y de Reformas a la ley No. 641, Código Penal.).

Ironically, only femicide is omitted. The Reform also states that mediation can only go forward if the accused does not have a prior record in any of these crimes. Nonetheless, the Reform is a dangerous, ludicrous reversal of the initial stance of the National Assembly, the Supreme Court, and the grass-roots elements of civil society that spent almost a year studying legislation and judicial practice to find viable methods of transforming institutions and stemming gender violence.

Immediately, feminist organizations began to denounce the government's actions. The Autonomous Women's Movement released a statement explaining how the Reform fostered the culture of impunity in Nicaragua:

The social message that is sent from the State with the reform is lethal, not only because this restitution [of mediation] implies the promotion of impunity, but also because it makes the State and all its operators into necessary accomplices of violence... what it does is deliberately consent to and favor perpetrators of crimes, and, as a consequence, leaves women completely defenseless (MAM, quoted in Montenegro et al. 2014, p. 4). ${ }^{25}$

Wilfredo Navarro, the representative who supported the draft bill (and who was one of only four assembly members who voted against the October 2013 Reform) said that it was counterproductive, given that "It [Law 779] hasn't even

25 "El mensaje social que se envía desde el Estado con la reforma es letal, no sólo porque esa restitución implica la promoción de la impunidad, sino porque convierte al Estado y a todos sus operadores en cómplices necesarios de la violencia... lo que hace es consentir y favorecer deliberadamente a los perpetradores del delito y, en consecuencia, deja a las mujeres en total indefensión". 
been permitted to develop" (Fernández, 2013). After two separate commissions, one governmental and one from civil society, had carried out such a careful study of the conjuncture and the need to prohibit mediation, the government's reversal of its stance bypassed these findings. Unfortunately, this degradation of Article 46 would not be the last blow to Law 779 .

\section{Regulation to Law 779, July 2014}

Less than a year later, Daniel Ortega's Regulations to Law 779 were released with no public or legislative discussion and little fanfare in La gaceta on July 31, 2014. Essentially gutting the initial language and gesture of the law, the presidential decree confines the definition of femicide to "the crime committed by a man against a woman in the frame of interpersonal couple relationships, and as a result giving death to the woman." 26 Illustrative of a complete reversal of the Ortega government's stance on gender violence, the decree establishes the Family Offices/ Counsels (Consejerias Familiares), community based institutions integrated by local volunteers, pastors, religious leaders, and judicial facilitators, with which women will be obligated to consult before filing a complaint with the police through the Women and Children's Police stations (Comisaria de la Mujer y la Niñez).

While the law originally prohibited mediation, Ortega's decree institutionalizes it and places the process in the hands of some of society's most conservative sectors. It is no exaggeration to affirm that the decree completely neutralizes the judicial empowerment of women and reinstitutes the family-i.e. patriarchal authority-as the social good to be protected by the law. As the first line of the Reglamento states: "the objective of Law 779 is to guarantee the strengthening of Nicaraguan families through actions of prevention that promote the right to life, dignity, equality, and non-discrimination in the relationships between men and women" (Asamblea Nacional de Nicaragua, 2014)." 27 While Article 1 of the original law states as its objective "to act against the violence that is exercised towards women," the fact that the Regulations to Law 779 appeal to the "strengthening of Nicaraguan families" implies that the focus changes from the protection of women as individuals, to the restoration of the family unit. The Movement for Sandinista Renovation, (Movimiento Renovador Sandinista - MRS) released a comparative chart that shows that the focus of the Regulations is family co-existence and cohabitation, rather than the rights of women.

More convincing evidence of the reactionary nature of the Regulations to Law 779 cannot be found than that in Article 8, the "Sphere of attention of the Family Counsels," which includes the following description:

26 "El mensaje social que se envía desde el Estado con la reforma es letal, no sólo porque esa restitución implica la promoción de la impunidad, sino porque convierte al Estado y a todos sus operadores en cómplices necesarios de la violencia... lo que hace es consentir y favorecer deliberadamente a los perpetradores del delito $y$, en consecuencia, deja a las mujeres en total indefensión".

27 "Que el objetivo de la Ley 779 es garantizar el fortalecimiento de las familias nicaragüenses mediante acciones de prevención que promuevan el derecho a la vida, dignidad, igualdad y no discriminación en las relaciones entre mujeres y hombres" (Ibid, 6263). 
During the family counseling for a woman, the partners or families will listen to them, accompany them, and psychologically assist them, so that the causes that could be producing any type of disturbance in interpersonal relationships can be recognized within their family dynamic, and mechanisms for reestablishing family harmony, based on communication, respect, mutual support, and love through compromise, will be provided to them ${ }^{28}$ (6265).

Effectively, any acknowledgement of the unequal power relations between masculinities and femininities is erased from the Law, replaced by a forced, superficial vocabulary of reconciliation: compromise, peace, harmony. All of these are terms that mean very little when one member of the family is mobilizing intimidation, dominance, and various types of physical violence to maintain control.

The Regulations also seem to put institutional control in the hands of the Ministry of the Family, Adolescence, and Childhood, stating that the Family Counsels will function on the community level and through this Ministry (Article 8). However, the language of the Regulations doesn't offer a clear path that women should take, complicating what had already been a complicated institutional process of denouncing violence. According to the RMCV's statement about the Regulations:

Women will have the option of going to the Women's Police Stations or to the Public Ministry, who will remit them to the Ministry of the Family with a summary of the situation in order to offer specialized family counseling services, expounds Article 10 of the Regulation. After passing through all these proceedings the woman will finally be able to go to the authorities (Pronouncement of the RMCV).

Supposedly, once in the Ministry of the Family "the couple can voluntarily receive psychosocial attention and have the opportunity to establish compromises" (Reglamento, Article 10) (Asamblea Nacional de Nicaragua, 2014). The protagonist position given to the Ministry of the Family is troubling for various reasons. According to Lourdes Bolaños et al. (2008), in their Diagnostic Report on Intrafamilial and Sexual violence, the Ministry of the Family doesn't have a special program to address VIFS [intrafamilial and sexual violence]: “...it's priority is the family as the fundamental nucleus of society, it's purpose is the restitution of values and the strengthening of community leadership in search of a solution to these problems" (p. 50).

All of these aspects demonstrate that the Regulations will place delicate, violent situations in the hands of people with no training in issues of gender violence, whose focus is on the maintenance of familial bonds. The problem with sending untrained people to "mediate" is that religious values and "common sense" knowledge about

28 "Durante la consejería familiar a la mujer, las parejas o familias se les escuchará, acompañará, atenderá psicológicamente, para que reconozcan las causas que les puede estar produciendo cualquier tipo de alteración en las relaciones interpersonales dentro de su dinámica familiar y se les facilitará mecanismos para que restablezcan la armonía familiar basados en la comunicación, el respeto, el apoyo mutuo y el amor a través de compromisos" (6265). 
relationships will most likely win out. This cannot favor the interests of women attempting to get out of a violent cycle. If the very objective and mission statement of the Regulations is to preserve the family, gender violence will no longer be treated as a fatal threat, nor with the due seriousness it deserves by these institutions.

On September 23, 2014 Sofía Montenegro and a group of lawyers, sociologists, and psychologists presented the "Recourse against the Regulations to Law 779" before the Supreme Court, alleging the unconstitutional nature of the presidential decree. This move happened in a parallel fashion to the public denunciation that was taking place among feminist groups. The Autonomous Women's Movement declared that

In the case of the Regulations to Law 779, Ortega constituted himself as the National Assembly, changed the objective of the law, reformed the crime of femicide, reduced the sphere of its application, gave functions to structures that are not legally valid... placed obstacles to the access to justice, and created structures that will have functions corresponding to those of the police and judicial organs (Movimiento Autónomo de Mujeres de Nicaragua, 2014).

Many other journalists and prominent public figures spoke out about the illegality of the Regulations. Not only in the opposition party, the MRS, but a broad range of civil society groups demonstrated worry about such a unilateral reversal of a democratically established law.

In addition to the Family Counsels being unqualified to mediate in terms of a gender perspective, neither are they trained in principles of judicial proceedings. Furthermore, as Sofía Montenegro points out, they are not a valid governmental body, as they were not created or approved by the National Assembly, but rather unilaterally appointed by Daniel Ortega. Besides, there seems to be confusion about their jurisdiction and how the Regulations to the law will be mobilized. After the Regulations were passed, President of the Supreme Court Alba Ramos reported that some judges had appealed to her court for a reform to the Regulations, given that they perceived inconsistencies in the document. Jumping to defend the Regulations, Ramos said they were "adjustments that need to be made for interpretation, no more than words that in their moment will be made known" (Martínez, 2014).

Even the Catholic Church has expressed hesitance and confusion about its possible role in mediating judicial conflicts. In the article "We aren't judges, or police officers, we're the Church” published in La Prensa, Bishop René Sándigo of the Episcopal Congress of Nicaragua asked that President Ortega clarify the content of the Regulations, stating that the work that the Church completes with the family is from the perspective of evangelical doctrine, "the Church cannot prosecute, nor condemn the family in the sphere of application of justice" (Chamorro Mendieta, 2014).

The underlying result of the Regulations seems to be not only confusion, but also a public erasure of gains made in the past two years. The Regulations are principally a shrugging off of the State's responsibility in protecting women and offering swift, efficient access to justice. According to the RMCV 
Contrary to the state's obligation to protect the victims of crimes/felonies, these counsels in practice try to submit women to mediations and/or obligatory conciliations, as well as violating their rights with re-victimizing procedures that could expose them to public ridicule and blame" (Miranda Aburto \& Montoya, 2014).

The reinstatement of mediation places many obstacles in the path of women who attempt to leave their aggressors because it opens the floodgates to a variety of revictimizing practices. In a deeply disappointing development, it annuls the very legal advances that had been made towards stemming these practices. The institutional quagmire, in addition to a muddled vision of who is qualified to mediate in situations of violence, will inevitably translate to an increased vulnerability for victims of gender violence. In the words of the Autonomous Women's Movement, Ortega “... destroyed the system of attention to victims of violence and complicated the route of access to justice, which puts the life and integrity of women at a greater risk, from which only a misogynist and criminal state can result" (Movimiento Autonómo de Mujeres de Nicaragua, 2014).

\section{Mediation: The feminine under surveillance and power-knowledge dynamics in the judicial realm}

Drawing mainly from the arguments against mediation presented by Nicaraguan feminist organizations, such as the Feminist Current (Programa Feminista La Corriente, 1997), the Autonomous Women's Movement, and the RMCV, and from the Nicaraguan Supreme Court as well, we can conclude that feminist resistance to this practice hinges mainly on the protection and preservation of women's lives. In their denouncement of the Reform to Law 779, the Autonomous Women's movement affirmed that before the instatement of Law 779, aggressors who had gone through mediation "reinforced their abusive practices against women and submitted them to reprisals after making [mediated] agreements" (Fernández, 2013). Furthermore, as an indicator of the former ubiquity of mediation as an institutional practice, María Auxiliadora Meza Gutiérrez reported in a 2006 study that of 559 crimes analyzed, 57 were resolved through mediation in cases of rape, statutory rape, and dishonest abuse, even though the Penal Code at the time supposedly prohibited mediation in "serious felonies" [delitos graves] (quoted in D'Angelo et al., 2008, p. 19). This explains why prohibiting mediation strengthened the other protections codified in the law, making Law 779 a truly integral approach to stopping violence. According to the Exposition of Motives for the draft bill of the law, presented to the National Assembly by the President of the Nicaraguan Supreme Court, Alba Ramos, in January 2012:

One of the difficulties or limitations presented by existing laws is that they punish the modality of violence that occurs in the domestic or intrafamiliar space, assuming that the protected subject is the family, because of this they 
don't protect women... The deaths of women originated after an inadequate sanction or after mediation" (unpaged, my emphasis). ${ }^{29}$

As Ramos's statement shows, the endorsement of the highest court in Nicaragua of the prohibition on mediation signified a benchmark decision towards protecting women's lives. In these institutional contexts, treating the family unit as more valuable than its individual members constitutes a secondary violence, a form of re-victimization. But even more than this, it means that the State does not fulfill its duty to protect citizens. It places a symbolic and imaginary unity above the physical well-being of individuals, namely girls and women survivors of violence.

Here I will explore several feminist criticisms of mediation as an institutional practice that touch the pragmatic and the symbolic levels of culture. These critiques dissect the superficial political discourses of familial reconciliation that serve to disguise coercion in the family structure, which in turn perpetuate feminine submission. They also attempt to dismantle essentialist discourses that naturalize women's role as "angel of the hearth" or protector of the family, which place an inordinate burden on women to keep the family together, suffering and appeasing violent masculinities. Finally, the feminist critiques take on the medico-juridical discourse that constructs women as "victims," as objects of knowledge-power, based on politics of "asistencialismo" and "tutelaje." These are institutional tendencies of belittlement that in fact perpetuate antiquated legal mechanisms for controlling women and their assets, such as patria potestad. In Nicaragua, the State is implicated in promoting masculine supremacy at all of these levels. Let us remember MacKinnon's poignant critique of State power: "State behavior that promotes and institutionalizes male dominance has been found to distinguish public from private, naturalize dominance as difference, hide coercion behind consent, and obscure sexual politics behind morality" (MacKinnon, 2006, p. 4).

Familial reconciliation is a strong motif in Nicaraguan political history. For this reason, appeals to the preservation of the Nicaraguan family proved to be an effective rhetorical strategy for those who opposed Law 779. Reliant on normative morality and an imaginary of protection and peace in unity, these discourses echoed the conciliatory discourses mobilized by Violeta Barrios de Chamorro during the 1990 presidential campaigns, after almost a decade of bitter conflict between Sandinismo and the U.S.-backed Contra army. Then, and during her presidency, Doña Violeta's image in the press and her own self-representation revolved around her as "a loyal wife and widow, reconciling mother, and Virgin Mary" and played on a theme that has been prevalent in right-wing politics in Latin America: "...the triumph of traditional femininity over political divisions and the apparent eliminations of such divisions through motherhood" (Kampwirth, 2004, p. 40). Indeed, the mobilization of the family unity discourse in the crusade against Law 779 probably appealed to Nicaraguan publics on a deep level due to just such symbolic appeals to motherhood/

29 "Una de las dificultades o limitantes que presentan las leyes existentes es que sancionan la modalidad de violencia que ocurre en el espacio doméstico o intrafamiliar, asumiendo que el sujeto protegido es la familia, por lo tanto no protege a la mujer... Las muertes de mujeres se originaron después de una sanción inadecuada o después de una mediación.” Debates parlamentarios, 31 January, 2011. See: http://www.asamblea. gob.ni/trabajo-legislativo/diario-de-debates/ 
the family as a source of peace in the conflictive Post-war years.

These family preservation discourses presuppose the family as a site exempt of power dynamics, and in fact mirror how the figure of mediation has functioned institutionally. Any assumption that aggressors and accusers can meet to dialogue and come to a compromise supposes that participants enjoy equal standing and prestige. This perspective circumvents the bare dynamics of dominance and submission that, more often than not, coalesce in the family around a dominant, abusive masculine presence. To ignore this power imbalance is to tacitly accept masculine supremacy and ascribe to an authoritarian model of the family: that it is normal for a man to have two women, that it is normal that he hit the children, that denouncing violence breaks up the family, and that economic necessity means women must suffer through abuse.

As Barragán (2007) notes in her study of re-victimization in institutional practices in the Bolivian justice system, it is extremely difficult to combat these types of logic in the "scenes of justice" [los escenarios de la justicia], when "In the family environment, the good [bien] that is preserved above all else is the family, a term that conceals, in reality, patriarchal and masculine authority associated with the provider" (p. 15). A study carried out by the Pan American Health Organization found that women face gender inequalities that expose them to distinct forms of discrimination and violence that are supported by:

...an authoritarian model of the family, in which respect is not understood as reciprocity between its members, but rather is defined by a structure of power based on the acceptance of masculine superiority... in which, also, violence is considered a legitimate tool for the preservation of the appropriate family order (quoted in Bolaños et al., 2008, p. 13)

Therefore, while Law 779 took strides towards deconstructing this prevailing model of the family, the terms used in the Regulations to Law 779, such as respect, mutual support, and harmony, must be exposed as deceptive and insufficient to tackle the extreme actions of violent masculinities. In the absence of institutional protection, with the enshrinement of re-victimizing practices, these dominating masculinities will find as much cultural support as they did before Law 779 .

A second aspect of the feminist critique of the ideology of mediation is that it places extreme pressure on women to suffer and bear abuse in order to salvage the family unit. This discursively displaces blame for violence onto the woman alone, excusing violent masculinities. During the legislative debates for the Reform of Law 779, Corina Leiva, a representative for the Independent Liberal Party declared that: "women are made to conserve the home, not to destroy it" (Fernández, 2013). This type of a discourse shows how, in the case of Nicaragua, women are held responsible for family harmony, and as a correlation, often they are held responsible for men's sexual crimes. In her study of sexual abuse and incest in the Nicaraguan newspapers, Ileana Rodríguez (2009) claimed that these sorts of narratives propagate a naturalization of abuse, rather than a naturalization of human rights. She claims that placing the blame on families, i.e. women, instead of the State in cases of sexual abuse is common in "failed or weak States": 
...where the nature/nurture divide is not marked by a strict division between the public and private as in other States. Little or no governance, State evasion of responsibilities is clear when women are publicly held accountable for men's sexual crimes and when mass media espouses the idea of family responsibility as opposed to the State's obligation to protect the rights of children. Blaming the victims and naturalizing behavior is perhaps the stimulus and protective mantle that culture extends to men. (p. 39)

To assert that women who refuse to mediate "destroy the family" is to naturalize and excuse masculine violence. Given that comments like Representative Leiva's commonly circulated about Law 779, blaming feminists for the destruction of the family, it is clear that Rodríguez's claim extends to the naturalization of the various forms of masculinist violence that exist at the heart of the family. Rather than fostering a space for assertions of feminine autonomy, it is most likely that mediation proceedings will instead replicate naturalizing discourses, forcing women to accept blame for the abusive actions of male family members.

Finally, mediation may be thought of as an approach to gender violence that considers women to be incapable, to be perpetual victims and second-class citizens. Known as "asistencialismo," these approaches see women survivors of violence as being in constant need of support and intervention. Rather than allowing for expanded autonomy or allowing them to guide their own processes, these institutional frameworks subject femininities to tutelage. In this sense, mediation may be the most egregious expression of subjecting women to scrutiny and questioning their decisions. Mediation through the Family Counsels would be a continuation and a boon to the tendency that already existed in police and judicial institutions to demean and infantilize women who attempt to assert their autonomy.

As Ana Carcedo Cabañas and Mónica Molina Subirós explain (2001), policies that are 'asistencialistas,' often result from the absence of aggressors on the institutional scene: "...institutions usually deal with women. From them they pull out all the information, they can dig in their lives, question, judge what they think and do, submit them to bribes and control" (p. 43). It remains to be seen how the Family Counsels will integrate aggressors into the mediation process. However, not much doubt remains among feminist organizations about the Regulations to Law 779 working as a mechanism to control women:

The structures it creates called "Family Counsels" will invade the privacy and decide, over the word, voice, and rights of women, who will be reduced to the category of "tutelaged" people without the capacity for their own agency and representation (Movimiento Autónomo de Mujeres de Nicaragua, 2014).

What Carcedo and Molina deem the central obstacle to women getting away from aggression, "the weight of social mandates on women to cede their personal projects to what the aggressor asks of them," will now be central in the justice system through processes of mediation (2001, p. 11). 
From the complete prohibition of mediation to placing mediation as a central tenet, the deformation and neutering of Law 779 tells the story of the boldfaced obstinacy of conservative sectors and elite groups whose social power depends on upholding the status quo of masculine authority. For this reason, mediation became the embattled juridical figure within the overall framework of Law 779, as opposed to other aspects, such as the definition of femicide, which did not receive as much criticism from the Catholic Church. Analyzing the feminist movement as a counterweight that attempts to even out the balance of power in favor of women in society allows us to perceive elite masculinities' death-grip on exclusive, hegemonic power. The prohibition of mediation threatened the interests of these conservative social actors. Women refusing to capitulate, dialogue, or compromise signaled a refusal to shoulder the burden of family structures that were disintegrating due to violent masculinities. Refusing to enter mediation, therefore, means subverting those forms of interpersonal violence that have been contiguous with masculine authority and that demonstrate its negligence of its purported duties and roles. Alongside the preservation of the personal safety of these femininities, then, on a symbolic level, refusing to enter mediation is a sign of resistance. It is a clear sign that the prestige of masculine, paternal authority is in deficit of its obligations. By prohibiting mediation, feminist groups are engaged in a struggle towards valuing the feminine over these failing traditional social structures.

Church leaders and municipal authorities with a strong stake in existing hierarchies in the family and community proved that they were unwilling to relinquish their cultural supremacy by admitting that the failure of paternal authority and responsibility represents a serious social crisis. That they would hold such a position, even in the face of the continual violation and violent annihilation of women, lays bare the deep roots of misogyny in authoritarian cultural modes and in the Christian narrative and symbolic tradition. As Sandra Ramos, leader in the María Elena Cuadra Women's Movement (Movimiento de Mujeres María Elena Cuadra), expressed it, "We felt that we were handed over once again to the demands of a highly conservative and misogynist ecclesiastical hierarchy that doesn't respect the women of this country" (Miranda Aburto, 2014).

\section{Conclusion}

Even though so many social actors fought for the passage of Law 779, the symbolic support for masculine authority is deep rooted in Nicaraguan culture. Perhaps the idea of the protective shell of the nuclear family, with a strong, protective father, represents an attractive bastion of order and stability. It is plausible that the fight against Law 779 was a regressive, defensive stance taken in the face of the undeniable social instability and deteriorating social bonds. As Connell explains, "[t]he incapacity of the institutions of civil society, notably the family, to resolve this tension [between the genders] provokes broad but incoherent state action (from family law to population policy) which itself becomes the focus of political turbulence" (1995, p. 85). Discourses fomenting mass anxiety about feminists attacking the institution of the family certainly proved an effective mobilization of political disaccord to the advantage of conservative sectors. 
There are many reasons to consider Law 779 as an organic, grassroots effort to address violence and to transform Nicaraguan cultural values in regard to gender relations. According to Domínguez Ruvalcaba (2013), "[u]nderstanding violence is basically a hermeneutic task, practiced by the community itself, in which violence becomes a form of communication" (p. 148). Though I am not from the community, I believe that Law 779 was just such a hermeneutic exercise, carried out by civil society and public officials in the hopes of deconstructing the language of violent masculinities in Nicaragua. Regardless, the intense social controversy over the law tells us that the "patriarchal pacts" between men in the Nicaraguan state do not cede easily to the pressure of recognizing gender inequality. In these adamant protests from men against national laws, who claim that they discriminate against men or are unconstitutional, Ana Carcedo Cabañas and Guiselle Molina Subirós (2001) identifed "[t]he resistance that exists to accept violence against women in reality, beyond the discourse, and to take it on as a problem of the disequilibrium/ imbalance of power between the genders" (p. 13).

The controversy over Law 779 in Nicaragua proves that law is not as separate from other social discourses as it would purport itself to be. Though it grants itself this specific privilege, it is permeable to interrogations, multiplicities, and deformations from a variety of (gendered) social interests (Threadgold, 1999, p. 372). The line between the law and public opinion is surely quite blurry in States where the Executive power bestows upon itself the ability to change the law at will. Through these gaps in legalistic framework and procedures, we see the fractures and sutures in the social link. The law cannot fix polarization and conflict in gender relations, but the law and the social debates it provokes will necessarily reflect them. We may need to look to the persistence of authoritarian modes of culture and to the ravages of neoliberal capitalism to understand the violent deaths of women that are resulting from this extreme gender polarization and crisis.

\section{References}

Amorós, C. (1990). Violencia contra las mujeres y pactos patriarcales. In V. Maquiera \& C. Sánchez (Comp.). Violencia y sociedad patriarcal. (pp. 39-53). Madrid: Fundación Pablo Iglesias.

Asamblea Nacional de Nicaragua. (2012, febrero). Ley No. 779, Ley Integral Contra la Violencia hacia las Mujeres y Reformas a la Ley No. 641, 'Código Penal'. La Gaceta: Diario oficial de la Asamblea Nacional. (35), Managua.

Asamblea Nacional de Nicaragua. (2014, July). Reglamento a la Ley 779. La Gaceta: Diario oficial de la Asamblea Nacional (143), Managua.

Babb, F. (2001). After Revolution: Mapping Gender and Cultural Politics in Neoliberal Nicaragua. Austin: University of Texas Press.

Barragán, R. (2005a). Absent Equality: Infamy, Patria Potestad, Legitimized Violence and its Continuities in Twentieth Century Bolivia. In M. A. Calderón Mólgora, W. Assies \& T. Salman (Eds.). Citizenship, Political Cultures and State Transformation in Latin America. (pp. 31-46). Amsterdam: Dutch UP.

Barragán, R. (2005b). The 'Spirit' of Bolivian Laws: Citizenship, Patriarchy, and 
Infamy. In S. Caulfield, S. C. Chambers \& L. Putnam (Eds.). Honor, Status, and Law in Modern Latin America. (pp. 66-86). Durham: Duke UP.

Barragán, R. (2007). Etnografía y hermenéutica de la justicia estatal: la violación como prisma de las relaciones sociales. In P. Calla (Coord.), R. Barragán, C. Salazar, C. Solíz and T. Arteaga. Rompiendo silencios: La violencia sexual y los desafíos al régimen de Género. Estudio para la Coordinadora de la Mujer. La $\mathrm{Paz}$, Bolivia.

Berlant, L. (2000). Intimacy. Chicago: University of Chicago Press.

Bernstein, E. (2010). Militarized Humanitarianism Meets Carceral Feminism: The Politics of Sex, Rights, and Freedom in Contemporary Antitrafficking Campaigns. Signs, 36(1), 45-71.

Blandón Gadea, M. T. (2011). Los cuerpos del feminismo nicaragüense. Managua: Programa Feminista La corriente.

Bolaños, M. L. et al. (2008). Diagnóstico de la violencia intrafamiliar y sexual en Nicaragua. Managua: Policía Nacional, Dirección Comisaria de la Mujer y la Niñez (Programa de Naciones Unidas para el Desarrollo).

Bumiller, K. (1987). Rape as a legal symbol: an essay on sexual violence and racism. University of Miami Law Review (42), 75-91.

Bumiller, K. (1988). The Civil Rights Society. Baltimore: Johns Hopkins UP.

Bumiller, K. (2008). In an Abusive State: How Neoliberalism Appropriated the Feminist Movement Against Sexual Violence. Durham: Duke UP.

Caputi, J. \& Russell, D. (1992). Femicide: Sexist Terrorism Against Women. In J. Radford \& D. Russell (Eds.). Femicide: The Politics of Killing Women. (pp. 13-24 New York: Twayne.

Carcedo Cabañas, A. \& Molina Subirós, G. (2001). Mujeres contra la violencia: una rebelión radical. San José: CEFEMINA.

Carranza Mena, M. \& Lara, R. (2013, September 11). Reforma a la Ley 779 apunta a la mediación con excepción. El Nuevo Diario. Retrieved on 12 September 2013, from http://www.elnuevodiario.com.ni/nacionales/296507-reforma-aley-779-apunta-a-mediacion-excepcion)

Chamorro Mendieta, E. (2014, septiembre 23). No somos jueces, ni policías, somos Iglesia. La Prensa. Retrieved on 24 September 2014, from http://www. laprensa.com.ni/2014/09/23/politica/213216-no-somos-jueces-ni-policiassomos-iglesia.

Connell, R. W. (1995). Masculinities. Berkeley: University of California Press.

D’Angelo, A., Molina, Y. \& Jubb, N. (2008). Mapeo de las Comisarias de la Mujer y la Niñez en Nicaragua. Quito: Centro de Planificación y Estudios Sociales (CEPLAES).

Domínguez Ruvalcaba, H. (2013). De la sensualidad a la violencia de género: La modernidad y la nación en las representaciones de la masculinidad en el México contemporáneo. México: CIESAS.

Fernández, J. (2013, September 28). Nicaragua aprueba permitir la mediacion entre agresores machistas y sus víctimas. El Diario.es. Retrieved on 29 September 2013, from http://www.eldiario.es/sociedad/Nicaragua-mediaciondenuncias-violencia-machista_0_179882016.html

Grewal, I. (2005). Transnational America. Feminisms, Diasporas, Neoliberalisms. Durham 
and London: Duke University Press.

Kampwirth, K. (2004). Feminism and the Legacy of Revolution: Nicaragua, El Salvador, Chiapas. Athens, Ohio: Ohio University Press.

Lacombe, D. (2010). El escándalo Ortega-Narváez o la caducidad del 'hombre nuevo': volver a la controversia. ISTOR, (40), 81-107.

Lagarde y de los Ríos, M. (2010). Preface. Feminist Keys for Understanding Feminicide: Theoretical, Political, and Legal Construction. In R. L. Fregoso \& C. Bejarano (Eds.). Terrorizing Women: Feminicide in the Américas. (pp. xixxv). Durham: Duke University Press.

Ley de Reforma y Adiciones a la Ley No. 779 Ley Integral Contra la Violencia Hacia las Mujeres y de Reformas a la ley No. 641, Código Penal. 1 de octubre de 2013.

MacKinnon, C. (2006). Are Women Human? And Other International Dialogues. Cambridge, Mass: Bellknap P of Harvard University Press.

Marti i Puig, S. \& Sánchez-Ancochea, D. (2014). Centroamérica hoy. Foreign Affairs Latinoamérica, 14(2), 107-113.

Martínez, I. (2014, septiembre 29). CSJ resolverá “en su debido tiempo" los recursos contra reglamento de Ley 779. La Prensa. Retrieved on September 30, 2014, from http://www.laprensa.com.ni/2014/09/29/nacionales/1242552-csjresolvera-en-su-debido-tiempo-los-recursos-contra-reglamento-de-ley-779.

Masson, S. (1999). Le viol en temps de guerre: crime ou bavure? Avancées et résistances de la condamnation du viol contre les femmes. Nouvelles Questions Féministes, 20(3), 63-80.

Miranda Aburto, W. (2014, August 16). Reglamento sepultó la ley 779. Confidencial. Retrieved on 17 August 2014, from http://www.confidencial.com.ni/ articulo/18940/reglamento-sepulto-ley-779.

Miranda Aburto, W. \& Montoya, F. (2014, August 8). Decretazo contra ley 779 es una 'orden suprema.' Confidencial. Retrieved on 09 August 2014, from http://www.confidencial.com.ni/articulo/18890/decretazo-contra-ley-779es-una-quot-orden-suprema-quot.

Montenegro, S. (1997). Nicaragua. Movimiento de Mujeres en Centroamérica. Managua: Programa Regional La Corriente.

Montenegro, S. (1999). La 'Herótica' nacional masculina. Debate feminista, 19(10), 223-227.

Montenegro, S. (2014, octubre 29). Nicaragua, el más equitativo en la desigualdad. Confidencial. Retrieved on 30 October, 2014, from www.confidencial.com.ni/ articulo/19962/nicaragua-el-mas-equitativo-en-la-desigualdad.

Montenegro, S., Jiménez Martínez, J. A., Mejía Palma, Y. C., Chow Cruz, M. A. \& Quirós Vísquez, A. O. (2014). Recurso de Amparo contra Reglamento a la Ley 779. Retrieved on 2 November, 2014, from http://www.confidencial.com.ni/ downloads/353.pdf.

Movimiento Autónomo de Mujeres de Nicaragua. (2014, August 14). Posicionamiento político del MAM en Rechazo al Ilegal Reglamento de Ley 779. Retrieved on 19 August 2014, from http://www.awid.org/esl/Las-Noticias-y-Analisis/ Temas-y-Analisis/Nicaragua-Posicionamiento-Politico-del-MAM-en-rechazo-alilegal-Reglamento-de-Ley-779. 
ND. (2014a, August 22). Nicaragua encabeza ranking de seguridad a nivel regional. El 19. Retrieved on August 23, 2014, from http://www.el19digital.com/ articulos/ver/titulo:21762-nicaragua-encabeza-ranking-de-seguridad-a-nivelregional.

ND. (2014b, November 02). Queremos poder vivir sin temor. La Prensa. Retrieved on November 03, 2014, from http://www.laprensa.com.ni/2014/11/02/ nacionales/1283304-14966.

ND. (2013, October 15). Mediación de Ley 779 no se está aplicando. El Nuevo Diario. Retrieved on October 16, 2013, from http://www.elnuevodiario.com.ni/ nacionales/299231-mediacion-de-ley-779-no-se-aplicando

Programa Feminista La Corriente. (1997). Movimiento de Mujeres en Centroamérica. Managua: Programa Regional La Corriente.

Rodríguez, I. (2009). Human Rights/Sexual Desires: Incest/Pedofilia/Rape. Hispanic Issues Online, 5(1), 37-51.

Romero, E. (2014, November 04). Violencia sin freno contra las mujeres. La Prensa. Retrieved on November 05, 2014, from http://www.laprensa.com. ni/2014/11/04/nacionales/216812-violencia-sin-freno-contra-las-mujeres

Sagot, M. (2012). ¿Un paso adelante y dos atrás? La tortuosa marcha del movimiento feminista en la era del neointegrismo y del 'fascismo social' en Centroamérica. In A. Carosio (Coord.). Feminismo y cambio social en América latina y el caribe. (pp. 75-100) Buenos Aires: CLACSO.

Fregoso, R. L. \& Bejarano, C. (2010). Terrorizing Women: Feminicide in the Americas. Durham: Duke University Press.

Threadgold, T. (1999). Law as/of Property, Judgment as Dissension: Feminist and Postcolonial Interventions in the Networks. International Journal for the Semiotics of Law, (12), 369-396.

Williams, P. J. (1991). The Alchemy of Race and Rights. Cambridge, Mass: Harvard University Press.

Valencia, S. (2010). Capitalismo gore. Madrid: Melusina.

Van Dijk, T. A. (2001). Critical Discourse Analysis. In D. Tannen, D. Schiffrin \& H. Hamilton (Eds.). Handbook of Discourse Analysis. (pp. 352-371). New York: Blackwell Publishing. 